\title{
AS PESSOAS CRESCIDAS, O SURDO E AMOR DOS ANIMAIS: A CRISE EXISTENCIAL NAS CRÔNICAS DE ANTÓNIO LOBO ANTUNES
}

\author{
Ana Lucia Jesus da Silva ${ }^{1}$; Tércia Costa Valverde ${ }^{2}$ \\ 1-Bolsista PROBIC/UEFS, graduanda em Letras com Espanhol, Universidade Estadual de Feira de Santana- UEFS, \\ analuci1799@gmail.com \\ 2- Orientadora, Departamento de Letras e Artes, Universidade Estadual de Feira de Santana- UEFS, \\ tecaverde05@outlook.com
}

PALAVRAS-CHAVE: Lobo Antunes; Crise do sujeito; Desconstrução social.

\section{INTRODUÇÃO}

António Lobo Antunes é um escritor português contemporâneo que revela um novo olhar para os acontecimentos históricos e sociais que ocorreram e ocorrem em Portugal e no Ocidente. Suas obras são também construídas através da memória e suas vivências. Ele utiliza, em seus romances e crônicas, a ironia, o grotesco e o riso para desconstruir todo o imaginário Português, criticando os acontecimentos e suas consequências que perpassam por toda a sociedade pós-moderna. A sociedade contemporânea ocidental passou e continua passando por grandes avanços tecnológicos, em que o homem da pós-modernidade encontrase deslocado e desorientado, entrando em colapso, cheio de sonhos e desejos frustrados. Uma das saídas encontradas por ele é o consumo excessivo, que garante apenas uma felicidade momentânea. Mesmo assim, o individuo capitalista agarra-se a essa ideia ilusória de falsa felicidade com todas as suas forças. Bauman (2001, p. 90), em Modernidade Líquida, expõe que, uma sociedade consumista baseia-se na comparação universal e que o céu é o único limite. Isso porque essas pessoas nunca estarão satisfeitas com os bens adquiridos, e sempre desejará mais novidades a serem consumidas. Este estudo tem por objetivo, analisar a crise de identidade do sujeito pós-moderno nas crônicas, As pessoas Crescidas, O Surdo e Amor dos Animais, de Lobo Antunes, através das ferramentas de desconstrução social: Ironia, grotesco e riso. Nas crônicas escolhidas para estudo, o presente autor discorre de diferentes maneiras a fragmentação do sujeito da pós-modernidade, seja pelo apego à infância, a rejeição dos avanços tecnológicos, os desejos e sonhos frustrados; pela loucura e a incerteza do futuro, temáticas que vão além da ficção, sendo facilmente encontrados na sociedade ocidental atual. A escrita Antuniana ecoa na vida de seus leitores, fazendo com que eles se identifiquem com os personagens, através de recortes e situações do cotidiano. Isso porque suas obras partem de uma base real, mostrando que o ser humano passa por momentos felizes e tristes, ao contrário do que prega a sociedade pós-moderna, em que o individuo tem que ser sempre o melhor em tudo o que faz. Lobo Antunes desconstrói essas ideias, revelando, ficcionalmente, que o ser humano é falho, fraco e imperfeito, e que utiliza, na sociedade, máscaras para esconder seus fracassos e debilidades. Arnaut (2009, p. 35) revela que não se pode deixar de apontar as frustrações e agonias que se presentificam nos vazios emocionais, das almas atormentadas que habitam os personagens antunianos. A partir das questões propostas, pretendemos fazer um breve estudo da crise identitária do sujeito pós-moderno nas crônicas: As pessoas Crescidas, O Surdo e Amor dos Animais, mostrando, de forma crítica, a degradação do indivíduo na sociedade ocidental.

\section{MATERIAL E MÉTODOS OU METODOLOGIA}

O procedimento utilizado para a realização da pesquisa foi a leitura de livros e artigos, de fichamentos dos textos teóricos, na produção de artigos para publicação e apresentação em 
eventos acadêmicos e das discussões no grupo de estudos antunianos. Foram utilizados teóricos como: Bauman (2001) que discute, a crise da sociedade pós-moderna e a fragmentação do sujeito; Arnaut (2009) e Blanco (2002) que tratam da fortuna critica de António Lobo Antunes; Kayser (1986) que aborda a questão do grotesco; Hutcheon (2000) que trata da ironia; e Bakhtin (2003) que trabalha o riso, dentre outros teóricos de grande importância para a temática proposta.

\section{RESULTADOS E/OU DISCUSSÃO}

As discussões e resultados do trabalho foram feitas também à partir dos nossos encontros no grupo de pesquisa Antuniana, na produção de artigos científicos e nas apresentações em seminários organizados pela Instituição UEFS. Os artigos produzidos foram: "A Memória em O Surdo de António Lobo Antunes", que trata da crise do homem pós-moderno e do seu apego pela infância; "A Crise Identitária do Sujeito Pós- Moderno na Crônica De Natal, de António Lobo Antunes", em que discutimos as angústias, a solidão, as frustrações e morbidez do individuo na atualidade; e "A Crise Identitária do Sujeito Pós-Moderno na Crônica $A$ Consequência Dos Semáforos, de António Lobo Antunes", que revela o cotidiano turbulento do individuo em meio aos avanços tecnológicos e às futilidades do mundo contemporâneo. Por fim, a obra antuniana pode sugerir, de modo irônico e grotesco, os problemas, angústias e frustações que o individuo da sociedade pós-moderna vivencia todos os dias, mostra a instabilidade e inseguranças que tais sujeitos presenciam diante da vida, dos seus sonhos não alcançados, ficando cada vez mais frio e individualista nas relações humanas, tornando-se um sujeito alienado sem esperanças e expectativas para o futuro, perdendo-se em um emaranhado de informações que não trazem respostas às dúvidas e incertezas que assombram as almas humanas.

\section{REFERÊNCIAS}

ANTUNES, António Lobo. Livro de Crónicas. 7.ed. Lisboa. Dom Quixote, 1998.

ANTUNES, A. L. Terceiro livro de crônicas. Lisboa: Dom Quixote, 2006. Disponível em: <<http://jardimdasdelicias.blogs.sapo.pt/23118.html>> acesso em 19 de abril às 17:00

ARNAUT, A.P. António Lobo Antunes. Lisboa: Edições 70, 2009.

BLANCO, M. L. Conversas com António lobo Antunes. 2.ed. Lisboa: Dom Quixote, 2002.

HALL, S. A identidade cultural na pós-modernidade. Tradução Tomaz da Silva e Guaracira Louro. 7.ed. Rio de Janeiro: DP\&A, 2002.

HUTCHEON, L. Teoria e política da ironia. Tradução Julio Jeha. Belo Horizonte: Editora UFMG, 2000.

KAYSER, W. O grotesco: configuração na pintura e na literatura. São Paulo: Perspectiva, 1986.

LE GOFF, J. História e memória. Tradução: Irene Ferreira, Bernardo Leitão e Suzana Borges. 5.ed. Campinas: Editora da UNICAMP. 1996.

VALVERDE, Tércia Costa. Ensaios: teoria e crítica literária; [prefácio José Rodrigues de Paiva]. - Salvador: EDUNEB; Feira de Santana: UEFS Editora, 2014. 